\title{
Inheritance of Resistance in Tomato to Race T3 of the Bacterial Spot Pathogen
}

\author{
J.W. Scott ${ }^{1}$ \\ Gulf Coast Research and Education Center, University of Florida, Institute of Food and Agricultural \\ Sciences, $500760^{\text {th }}$ Street East, Bradenton, FL 34203-9324
}

\author{
J.B. Jones \\ Plant Pathology Department, University of Florida, Institute of Food and Agricultural Sciences, 2515 \\ Fifield Hall, P. O. Box 110680, Gainesville, FL 32611-0680 \\ G.C. Somodi \\ Gulf Coast Research and Education Center, University of Florida, Institute of Food and Agricultural \\ Sciences, $500760^{\text {th }}$ Street East, Bradenton, FL 34203-9324
}

\begin{abstract}
AdDITIONAL INDEX wORDs. disease resistance, hypersensitivity, Lycopersicon esculentum, plant breeding, Xanthomonas campestris pv. vesicatoria

Abstract. Hawaii 7981 tomato (Lycopersicon esculentum Mill.), resistant to race T3 of the bacterial spot pathogen [Xanthomonas campestris pv. vesicatoria (Doidge) Dye], was crossed to the susceptible tomato inbred, Fla. 7060, and subsequently $F_{2}$ and backcross seed were obtained. These generations were planted in the field, inoculated with the race T3 pathogen and evaluated for disease severity over two summer seasons. Data were tested for goodness-of-fit to a model based on control by the incompletely dominant gene $X v 3$ that confers hypersensitivity. The $F_{1}$ was intermediate in disease severity to the parents for both seasons. When data were combined over both seasons, the backcrosses fit the expected 1:1 ratios although each deviated from the expected ratio in one of the 2 years tested. The $F_{2}$ did not fit the expected 1:2:1 ratio in either year or when data from the two years were combined due to a deficiency of resistant plants. Thirty-three $F_{2}$ plants representing an array of disease severities and hypersensitivity reactions were selected in the second season and their $F_{3}$ progeny were inoculated and evaluated for disease severity. Hawaii 7981 was significantly more resistant than the 12 most resistant $F_{3}$ selections even though all expressed hypersensitivity. A hypersensitive $F_{3}$ with intermediate field resistance was crossed to Hawaii 7981 and subsequently, $F_{2}$ and backcross generations were obtained. These generations were field inoculated with the race $\mathrm{T} 3$ pathogen and evaluated for disease severity. Hawaii 7981 was significantly more resistant than the $F_{3}$ parent as in the previous year. The data did not fit an additive-dominance model and epistatic interactions were significant. Thus, it appears that field resistance to race T3 of bacterial spot found in Hawaii 7981 is conferred quantitatively by $X v 3$ and other resistance genes. Breeding implications are discussed.
\end{abstract}

Three races of bacterial spot, incited by Xanthomonas campestris pv. vesicatoria, infect tomato (Lycopersicon esculentum). These have been designated T1, T2, and T3 as described by Jones et al. (1995). In Florida, T1 was the endemic race, but it has been largely replaced by $\mathrm{T} 3$ probably due to antagonism of T3 over T1 (Jones et al., 1998). This has occurred in the absence of $\mathrm{T} 1$ resistant cultivars. Because bacterial spot is difficult to control by chemical means, especially during hot, rainy weather common in Florida early in the fall production season, host resistance seems an attractive control strategy. Field resistance to race T1 was found in Hawaii 7998 (Scott and Jones, 1986). This resistance was reported to be complex and unusual. Scott and Jones, (1989) reported field resistance to be largely additive and controlled by three to five effective factors. Whereas hypersensitivity is generally controlled by single dominant genes, the race T1 hypersensitive response of Hawaii 7998 was controlled by either two (Whalen et al., 1993) or three genes (Wang et al., 1994). Later, Yu et al. (1995) discovered three regions of the genome were in fact associated with the hypersensitive response. However, field resistance was not explained by the hypersensitive response alone. Scott and Jones (1989) reported only $5 \%$ of $\mathrm{F}_{2}$

Received for publication 3 Nov. 2000. Accepted for publication 2 Apr. 2001. Florida Agricultural Experiment Station journal series R-07852. The cost of publishing this paper was defrayed in part by the payment of page charges. Under postal regulations, this paper therefore must be hereby marked advertisement solely to indicate this fact.

1E-mail: jwsc@gnv.ifas.ufl.edu. plants were resistant in the field, but $\approx 60 \%$ were hypersensitive. Wang (1992) reported correlation coefficients of only 0.39 to 0.41 between hypersensitivity and field resistance in two field $F_{2}$ populations. Later, Somodi et al. (1996) found correlation coefficients of 0.31 to 0.52 between hypersensitivity and field resistance in two $\mathrm{F}_{2}$ populations.

Hypersensitive resistance to race $\mathrm{T} 3$ was discovered in Hawaii 7981 and L. pimpinellifolium L. accessions PI 126932 and PI 128216 (Jones et al., 1995). The highest level of resistance in the field was in Hawaii 7981 (Scott et al., 1995). In a growth chamber experiment, the hypersensitive response in Hawaii 7981 was determined to be controlled by an incompletely dominant gene designated $X c v-3$ (Scott et al., 1996) although $X v 3$ is now the preferred gene designation and will be used herein. The objective of this study was to characterize inheritance of race $\mathrm{T} 3$ bacterial spot resistance in the field. This information will be useful in developing breeding strategies to incorporate $\mathrm{T} 3$ resistance into commercial cultivars.

\section{Materials and Methods}

1994 EXPERIMENT. The race T3 susceptible inbred Fla. 7060 was crossed to Hawaii 7981, and subsequently the $F_{1}$ was selfpollinated to produce $F_{2}$ seed and crossed to each parent to produce backcrosses. These generations were used for inheritance studies in 1994 and 1995. Seed were sown in a greenhouse in Black Beauty spent coal (Reed Minerals Div., Highland, Ind.) 
Table 1. Summer 1994, 1995, and combined disease ratings for tomato genotypes Hawaii 7981 (resistant), Fla 7060 (susceptible) and derived generations after inoculation with Xanthomonas campestris pv. vesicatoria race T3 and chi-square tests for control of resistance by a single incompletely dominant gene.

\begin{tabular}{|c|c|c|c|c|c|c|c|c|c|}
\hline \multirow[b]{2}{*}{ Genotype } & \multirow[b]{2}{*}{ Generation } & \multirow[b]{2}{*}{ Years(s) } & \multirow{2}{*}{$\begin{array}{l}\text { Total } \\
\text { plants }\end{array}$} & \multicolumn{3}{|c|}{ Disease rating ${ }^{z}$} & \multirow{2}{*}{$\begin{array}{c}\text { Expected } \\
\text { ratio }\end{array}$} & \multirow[b]{2}{*}{$\chi^{2}$} & \multirow[b]{2}{*}{$P$} \\
\hline & & & & $<3$ & $3-4$ & $>4$ & & & \\
\hline \multirow[t]{3}{*}{ Hawaii 7981 (7981) } & \multirow{3}{*}{$\mathrm{P}_{1}$} & 1994 & 28 & 23 & 5 & 0 & 1:0:0 & --- & --- \\
\hline & & 1995 & 29 & 29 & 0 & 0 & & --- & --- \\
\hline & & $\Sigma$ & 57 & 52 & 5 & 0 & & --- & --- \\
\hline \multirow[t]{3}{*}{ Fla. 7060 (7060) } & \multirow[t]{3}{*}{$\mathrm{P}_{2}$} & 1994 & 30 & 1 & 0 & 29 & $0: 0: 1$ & --- & --- \\
\hline & & 1995 & 30 & 0 & 8 & 22 & & --- & --- \\
\hline & & $\Sigma$ & 60 & 1 & 8 & 51 & & --- & --- \\
\hline \multirow[t]{3}{*}{$7060 \times 7981$} & \multirow[t]{3}{*}{$\mathrm{F}_{1}$} & 1994 & 30 & 5 & 25 & 0 & $0: 1: 0$ & --- & --- \\
\hline & & 1995 & 30 & 5 & 25 & 0 & & --- & --- \\
\hline & & $\Sigma$ & 60 & 10 & 50 & 0 & & --- & --- \\
\hline \multirow[t]{3}{*}{ (7060 x 7981) 7981} & \multirow[t]{3}{*}{$\mathrm{BCP}_{1}$} & 1994 & 88 & 40 & 43 & $5^{\mathrm{y}}$ & $1: 1: 0$ & 0.73 & $0.5-0.1$ \\
\hline & & 1995 & 119 & 72 & 47 & 0 & & 4.03 & $0.05-0.025$ \\
\hline & & $\Sigma$ & 207 & 112 & 90 & $5^{y}$ & & 1.39 & $0.5-0.1$ \\
\hline \multirow[t]{3}{*}{ (7060 × 7981) 7060} & \multirow[t]{3}{*}{$\mathrm{BCP}_{2}$} & 1994 & 90 & 0 & 37 & 53 & $0: 1: 1$ & 2.84 & $0.1-0.05$ \\
\hline & & 1995 & 120 & $5^{\mathrm{y}}$ & 66 & 49 & & 5.25 & $0.025-0.01$ \\
\hline & & $\Sigma$ & 210 & $5^{y}$ & 103 & 102 & & 0.17 & $0.9-0.5$ \\
\hline \multirow[t]{3}{*}{$(7060 \times 7981)-\mathrm{Bk}$} & \multirow[t]{3}{*}{$\mathrm{F}_{2}$} & 1994 & 169 & 28 & 83 & 58 & $1: 2: 1$ & 10.69 & $<0.005$ \\
\hline & & 1995 & 208 & 37 & 118 & 53 & & 6.23 & $0.025-0.01$ \\
\hline & & $\Sigma$ & 377 & 65 & 201 & 111 & & 12.88 & $<0.005$ \\
\hline
\end{tabular}

${ }^{\mathrm{z}}$ Rated on scale of Horsfall-Barratt (1945) where $<3=0 \%$ to $3 \%, 3$ to $4=3 \%$ to $12 \%,>4=12 \%$ to $50 \%$ infected tissue.

yCombined with 3 to 4 disease rating for chi-square analysis.

medium on 16 June and seedlings were transplanted into Todd planter flats $\left(3.8 \mathrm{~cm}^{3}\right.$ cell size) (Speedling, Sun City, Fla.) on 27 June. On 25 July plants were transferred to $385 \mathrm{~cm}^{3}$ pots so that hypersensitivity could be measured by confluent necrosis as described elsewhere (Jones et al., 1995; Klement, 1982). Results of the hypersensitivity tests were ambiguous and will not be presented. Plants were transplanted to the field on 22 Aug. on 20$\mathrm{cm}$-high, 81-cm-wide beds of EauGallie fine sand (sandy, siliceous, hyperthermic Alfic Alaquod) that had been fumigated with $67 \%$ methyl bromide : $33 \%$ chloropicrin at $392 \mathrm{~kg} \cdot \mathrm{ha}^{-1}$ and covered with white polyethylene mulch 2 weeks before transplanting.

A randomized complete-block design was used with three blocks and 10 plant plots for the $\mathrm{P}_{1}, \mathrm{P}_{2}$, and $\mathrm{F}_{1}$ generation, 30 plant plots for the backcrosses, and 60 plant plots for the $\mathrm{F}_{2}$ generation. Plants were spaced $46 \mathrm{~cm}$ apart within plots that were $91 \mathrm{~cm}$ apart in rows, with $152 \mathrm{~cm}$ between rows. Recommended fertilizer and insecticide programs were followed (Hochmuth et al., 1989), and the label rate of 2,4,5,6-tetrachloroisophthalonitrile (chlorothalonil) was applied to control fungal pathogens. Plants were grown with stake culture and irrigated by seepage from ditches adjacent to the six experimental beds. Race T3 inoculum was produced by growing the bacteria on Difco nutrient agar (Becton Dickinson and Company, Sparks, Md.) for $24 \mathrm{~h}$ at $28^{\circ} \mathrm{C}$. Bacterial cells were removed from the agar plates and suspended in $10 \mathrm{~mm}$ $\mathrm{MgSO}_{4} \bullet 7 \mathrm{H}_{2} \mathrm{O}$ and the suspensions were standardized to $\mathrm{A}_{600}=$ 0.15 (a concentration of $\approx 10^{8}$ colony forming units $(\mathrm{cfu}) / \mathrm{mL}$ ). Inoculum was applied with a backpack sprayer early in the morning on 31 Aug. On 19 Sept. each plant was evaluated for bacterial spot disease severity by rating the two aisle sides of the staked plants using the scale of Horsfall and Barratt (1945) and then averaging two ratings per plant. The Horsfall-Barratt scale translates percentage of diseased tissue to numbers, where $1=$ $0 \%, 2=0 \%$ to $3 \%, 3=3 \%$ to $6 \%, 4=6 \%$ to $12 \%, 5=12 \%$ to $25 \%$, $6=25 \%$ to $50 \%, 7=50 \%$ to $75 \%, 8=75 \%$ to $87 \%, 9=87 \%$ to
$94 \%, 10=94 \%$ to $97 \%, 11=97 \%$ to $100 \%$, and $12=100 \%$ diseased tissue. Data were partitioned into resistant, intermediate, and susceptible categories based on distribution of the $\mathrm{P}_{1}, \mathrm{P}_{2}$, and $F_{1}$ generations so that chi-square analysis could be used to test for genetic control by $X v 3$, the single incompletely dominant gene that confers the hypersensitive response (Scott et al., 1996).

1995 EXPERIMENT. Seed were sown on 12 June, seedlings were transplanted to planter flats in the greenhouse on 21 June, and plants were transplanted to $385 \mathrm{~cm}^{3}$ pots on 27 July. Leaflets on each plant were injected in the greenhouse on 10 Aug. with a suspension containing $10^{8} \mathrm{cfu} / \mathrm{mL}$ so that hypersensitivity could be measured as in the 1994 experiment. Plants were transplanted to the field on 17 Aug., inoculated on 25 Aug., and rated for disease severity on 26 Sept. A randomized complete-block design with three blocks and 10-plant plots was used. Each block had one plot for the $P_{1}, P_{2}$, and $F_{1}$ generations, four plots for the backcrosses, and seven plots for the $\mathrm{F}_{2}$. Hypersensitivity reactions were evaluated in the field by the same method as used in the greenhouse in 1994. A new fully formed leaf was tagged and injected on 18 Sept. and confluent necrosis was evaluated at 24 and $48 \mathrm{~h}$. Seed was saved from $33 \mathrm{~F}_{2}$ plants that were selected on 16 Oct. They were selected for various combinations of disease severity and hypersensitivity and included nine highly resistant (Horsfall-Barratt $<3$ ) plants. All other procedures were as described for the 1994 experiment.

1996 EXPERIMENT. Seed of Hawaii 7981, Fla. 7060, their $F_{1}$ and $33 \mathrm{~F}_{3}$ lines from the $\mathrm{F}_{2}$ selections made in 1995 were sown on 10 June, seedlings were transplanted to planter flats on 20 June, and plants were transplanted to the field on 22 July. They were planted in a randomized complete-block design with three blocks and eight plants per plot. The plants were inoculated in the field by spraying a suspension $\left(10^{8} \mathrm{cfu} / \mathrm{mL}\right)$ of a mixture of $\mathrm{T} 3$ strains on the foliage in the morning of 12 Aug. Disease severity was rated on 24 Sept. Data were subjected to analysis of variance procedures and significant differences between $\mathrm{F}_{3}$ genotypes were 
determined by Duncan's multiple range test using "SAS For Windows" (SAS Inst., Inc., 1997). All other procedures were as described for the 1994 experiment.

1997 Experiment. To test for existence of resistance genes other than $X v 3$, Hawaii 7981 was crossed with E228 in Fall 1996. E228 was an $\mathrm{F}_{3}$ line selected for a strong hypersensitivity response comparable to that of Hawaii 7981 with less bacterial spot race T3 field resistance in the 1996 experiment. In Spring 1997 the $F_{1}$ was self-pollinated to produce $F_{2}$ seed and backcrosses were made with the parents. These generations and Fla. 7060, a susceptible control, were sown on 19 June. Seeds were transplanted to planter flats on 27 June, plants were transplanted to the field on 21 July and inoculated on 1 Aug. They were arranged in a randomized complete-block design with four blocks and 10 plants per plot for the control, $\mathrm{P}_{1}, \mathrm{P}_{2}$, and $\mathrm{F}_{1}$, and 25 plants per plot for backcrosses and $\mathrm{F}_{2}$ with two plots per block for the $\mathrm{F}_{2}$. Disease severity was rated 29 Aug. Hypersensitivity was evaluated in the field as described previously. A new fully formed leaf was tagged and injected on 19 Sept. and confluent necrosis was evaluated at 24 and $48 \mathrm{~h}$. Data were subjected to generation means analysis (Mather and Jinks, 1982) using a Lotus spreadsheet program $(\mathrm{Ng}$, 1990). All other procedures were as described for the 1994 experiment.

\section{Results}

Disease severity of the $F_{1}$ was intermediate between the resistant and susceptible parents in 1994 and 1995, supporting

Table 2. Bacterial spot race T3 disease severity and hypersensitivity reactions for Hawaii 7981, Fla. 7060, their $\mathrm{F}_{1}, 33 \mathrm{~F}_{2}$ plants selected for various levels of disease severity and hypersensitivity reactions in 1995 , and their $\mathrm{F}_{3}$ progeny in 1996.

\begin{tabular}{|c|c|c|c|c|c|}
\hline \multirow{3}{*}{$\begin{array}{l}\mathrm{F}_{3} \text { plot } \\
\text { designation }\end{array}$} & \multicolumn{2}{|c|}{ Summer $1995 \mathrm{~F}_{2}$ selection } & \multicolumn{3}{|c|}{ Summer $1996 \mathrm{~F}_{3}$ progeny } \\
\hline & \multirow{2}{*}{$\begin{array}{l}\text { Disease } \\
\text { severity }\end{array}$} & \multirow[b]{2}{*}{ Hypersensitivity $^{\mathrm{z}}$} & \multirow[b]{2}{*}{ Hypersensitivity $^{\mathrm{y}}$} & \multicolumn{2}{|c|}{ Disease severity } \\
\hline & & & & Mean & Range \\
\hline E212 & 5 & - & $+/-$ & $5.4 \mathrm{a}^{\mathrm{x}}$ & $4-7$ \\
\hline E218 & 5 & - & - & $5.2 \mathrm{a}$ & $3-6$ \\
\hline E215 & 4 & - & - & $5.0 \mathrm{a}-\mathrm{c}$ & $4-6$ \\
\hline E207 & 5 & - & - & $4.8 \mathrm{a}-\mathrm{d}$ & $4-6$ \\
\hline E225 & 3 & + & $+1-$ & $4.7 \mathrm{a}-\mathrm{d}$ & $2-6$ \\
\hline Fla. 7060 & $(4.7)$ & $(-)$ & $(-)$ & $4.7 \mathrm{~b}-\mathrm{e}$ & $4-5$ \\
\hline E234 & 4 & - & - & $4.5 \mathrm{~b}-\mathrm{f}$ & $2-6$ \\
\hline E208 & 4 & ++ & + & $4.3 \mathrm{c}-\mathrm{g}$ & $1-6$ \\
\hline E216 & 3 & +++ & + & $4.3 \mathrm{c}-\mathrm{g}$ & $3-5$ \\
\hline E232 & 3 & + & + & $4.3 \mathrm{c}-\mathrm{g}$ & $2-5$ \\
\hline E220 & 3 & ++ & $+1-$ & $4.1 \mathrm{~d}-\mathrm{h}$ & $2-5$ \\
\hline E204 & 3 & + & $+1-$ & $4.0 \mathrm{e}-\mathrm{h}$ & $3-5$ \\
\hline E209 & 3 & ++ & + & $4.0 \mathrm{e}-\mathrm{h}$ & $1-6$ \\
\hline E236 & 3 & + & $+1-$ & $3.9 \mathrm{f}-\mathrm{h}$ & $1-6$ \\
\hline E229 & 3 & + & $+/-$ & $3.8 \mathrm{~g}-\mathrm{i}$ & $1-5$ \\
\hline E223 & 4 & - & - & $3.8 \mathrm{~g}-\mathrm{i}$ & $2-6$ \\
\hline E228 & 3 & +++ & ++ & $3.7 \mathrm{~g}-\mathrm{j}$ & $3-5$ \\
\hline E230 & 3 & +++ & + & $3.6 \mathrm{~g}-\mathrm{k}$ & $1-5$ \\
\hline E210 & 5 & + & $+1-$ & $3.5 \mathrm{~h}-\mathrm{k}$ & $1-5$ \\
\hline E235 & 3 & + & $+1-$ & $3.5 \mathrm{~h}-1$ & $1-5$ \\
\hline E214 & 1 & ++ & $+1-$ & $3.5 \mathrm{~h}-1$ & $1-6$ \\
\hline E221 & 5 & +++ & $+1-$ & $3.2 \mathrm{i}-\mathrm{m}$ & $1-5$ \\
\hline E211 & 1 & +++ & ++ & $3.0 \mathrm{j}-\mathrm{m}$ & $1-5$ \\
\hline E231 & 1 & ++ & + & $3.0 \mathrm{j}-\mathrm{m}$ & $1-4$ \\
\hline $7060 \times \mathrm{H} 7981 \mathrm{~F}_{1}$ & $(2.9)$ & $(+)$ & $(+)$ & $3.0 \mathrm{j}-\mathrm{m}$ & $2-4$ \\
\hline E226 & 3 & +++ & + & $2.9 \mathrm{k}-\mathrm{m}$ & $1-6$ \\
\hline E206 & 1 & ++ & + & $2.81-\mathrm{n}$ & $1-4$ \\
\hline E213 & 3 & +++ & + & $2.6 \mathrm{~m}-\mathrm{o}$ & $1-5$ \\
\hline E222 & 3 & ++ & $+1-$ & $2.5 \mathrm{~m}-\mathrm{o}$ & $1-4$ \\
\hline E205 & 1 & ++ & + & $2.5 \mathrm{~m}-\mathrm{o}$ & $1-5$ \\
\hline E219 & 1 & +++ & ++ & $2.2 \mathrm{n}-\mathrm{p}$ & $1-4$ \\
\hline E217 & 1 & +++ & ++ & $2.1 \mathrm{op}$ & $1-4$ \\
\hline E224 & 1 & ++ & ++ & $2.0 \mathrm{op}$ & $1-4$ \\
\hline E227 & 3 & +++ & ++ & 1.9 op & $1-6$ \\
\hline E233 & 2 & ++ & + & $1.7 \mathrm{p}$ & $1-4$ \\
\hline Hawaii 7981 & $(1.1)$ & $(+++)$ & $(++)$ & $1.0 \mathrm{q}$ & $1-1$ \\
\hline
\end{tabular}

${ }^{\mathrm{z}}$ Based on speed and intensity of confluent necrosis from two tests (greenhouse and field) where -indicates no necrosis and,,+++ and +++ indicate increasingly rapid and intense necrotic responses, respectively.

y Based on the speed and intensity of the response of 6 to 12 plants per genotype in the greenhouse where - indicates no necrosis, $+/-$ indicates segregation for hypersensitivity, + indicates necrosis $48 \mathrm{~h}$ after injection, and ++ indicates necrosis $24 \mathrm{~h}$ after injection.

${ }^{x}$ Mean separation within column by Duncan's multiple range test at $P<0.05$. 
$H 7981\left(P_{1}\right)$
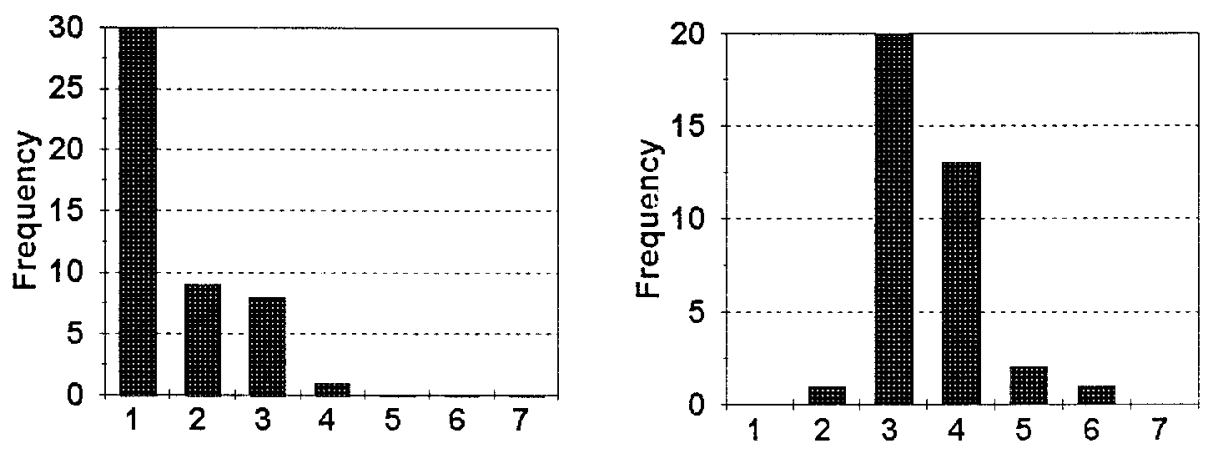

$\mathbf{F}_{1}$

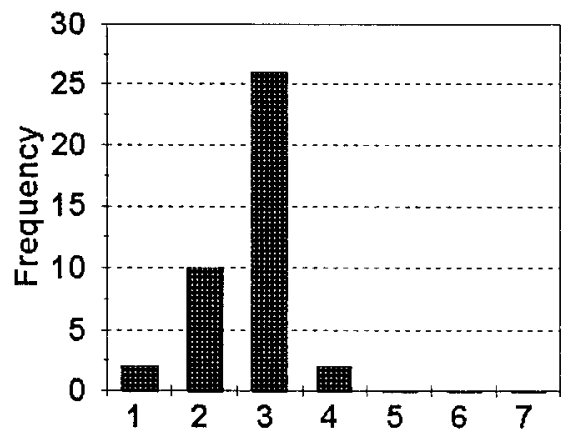

$B C P_{1}$

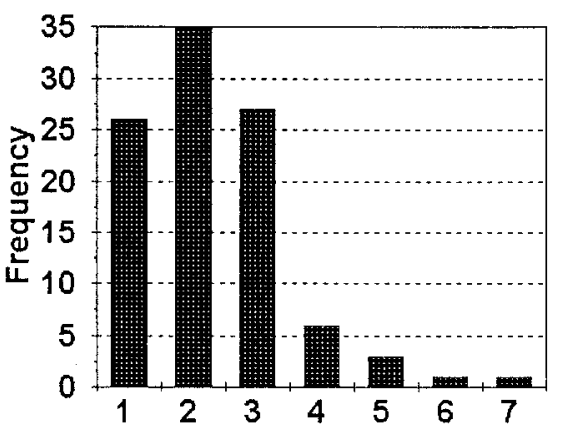

$\operatorname{E228}\left(P_{2}\right)$
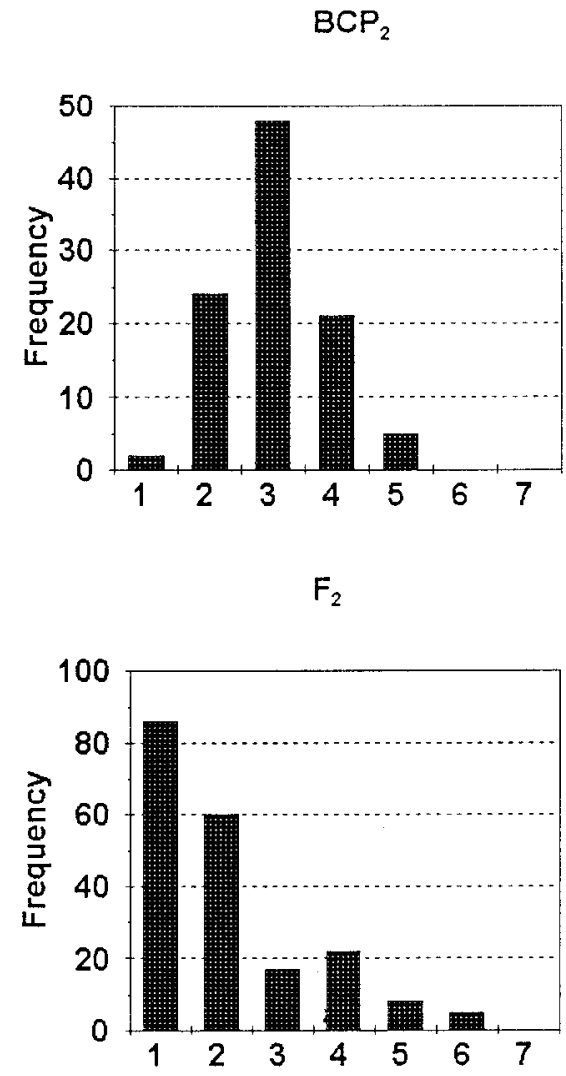

the expected 1:1 ratio of intermediate to susceptible plants (Table 1). The combined $\mathrm{F}_{2}$ data deviated significantly from the expected 1:2:1 ratio because of a deficiency of resistant plants and an excess of susceptible plants (Table 1). There was a deficiency of resistant plants both years. In 1995 there was an excess of intermediate plants, whereas in 1994 there was an excess of susceptible plants. From the backcross and $\mathrm{F}_{2}$ generations it was apparent that there was more disease pressure in 1994 than 1995. The deficiency of resistant plants in the $\mathrm{F}_{2}$ generation and inconsistent ratios for the backcrosses suggested that there might be more than one gene controlling resistance to race T3 from Hawaii 7981.

Data for the $\mathrm{F}_{3}$ progeny of the selected $\mathrm{F}_{2}$ plants lend support to the existence of genes other than a single hypersensitivity gene controlling resistance. Although nine $\mathrm{F}_{2}$ plants were selected for hypersensitivity and disease severity of $<3$, none of their $\mathrm{F}_{3}$ progeny nor any other $\mathrm{F}_{3}$ were as resistant as Hawaii 7981 (Table 2). This is reflected in their significantly higher means and their ranges that might indicate lack of homozygosity. Also, E223 did not express hypersensitivity, but was more resistant than susceptible Fla. 7060.

To explore the existence of resistance genes other than $X v 3$, a family derived from E228 crossed with Hawaii 7981, was evaluated in summer 1997. In 1997, E228 was not as resistant as Hawaii 7981 as was the case in 1996 (Tables 2 and 3; Fig. 1). As in 1996, E228 had significantly less disease than Fla. 7060 that had a rating of 5.68 in 1997 . The $F_{1}$ was intermediate between the parents and was skewed slightly towards susceptibility (Table 3; Fig. 1). The backcross to Hawaii $7981\left(\mathrm{BCP}_{1}\right)$ was distributed primarily between the $F_{1}$ and Hawaii 7981, but there were some plants more susceptible than the $F_{1}$ which resulted in higher than expected disease severity. The backcross to E228 was distributed between the $\mathrm{F}_{1}$ and E228 with less

Fig. 1. Bacterial spot race $\mathrm{T} 3$ disease severity frequency distributions for tomato parents Hawaii 7981 (H7981), E228 and generations derived from them at Bradenton, Fla., during Summer 1997. BC = backcross.

additive inheritance as would be expected with incomplete dominance (Table 1). The backcross to the resistant parent had an acceptable fit to the expected 1:1 ratio of resistant to intermediate plants in 1994 and when data were combined over both seasons. In the 1995 experiment, the observed frequency deviated significantly from the expected 1:1 ratio because of an excess of resistant plants. For the backcross to the susceptible parent the chi-square test was barely acceptable in 1994 because of a higher number of susceptible plants. In 1995 there were more intermediate plants than susceptible plants and the observed frequency deviated significantly from the expected ratio. However, when data were combined for the 2 years, there was an acceptable fit to

variation than $\mathrm{BCP}_{1}$. The $\mathrm{F}_{2}$ had a continuous distribution with a relatively high percentage of plants in the most resistant categories. This resulted in a $\mathrm{F}_{2}$ mean that was lower than expected and it was on the opposite side of the midparent value than the $F_{1}$ mean. The data did not fit an additive-dominance model, primarily due to deviations in $\mathrm{BCP}_{1}$ and $\mathrm{F}_{2}$ generations (Table 3).

Thus, an interaction analysis was performed that revealed significant homozygous $\times$ homozygous ([i]), homozygous $\times$ heterozygous ([j]), and heterozygous $\times$ heterozygous ([1]) interactions (Table 4). Because the [i] and [1] interactions had opposite signs, a duplicate dominant or recessive suppressor type of epistasis was indicated (Mather and Jinks, 1982). Both additive and dominant effects were significant. The epistasis prevented the estimate of effective factors, narrow sense heritability, and broad sense heritability. 
Table 3. Bacterial spot race T3 disease severity for Hawaii $7981\left(\mathrm{P}_{1}\right), \mathrm{E} 228\left(\mathrm{P}_{2}\right), \mathrm{F}_{1}, \mathrm{~F}_{2}$, and backcross generations and joint scaling test for goodness of fit to an additive-dominance model.

\begin{tabular}{|c|c|c|c|c|c|}
\hline \multirow[b]{2}{*}{ Generation } & \multirow{2}{*}{$\begin{array}{c}\text { Plant } \\
\text { no. }\end{array}$} & \multicolumn{2}{|c|}{ Mean disease severity ${ }^{z}$} & \multirow[b]{2}{*}{ Variance } & \multirow{2}{*}{$\begin{array}{c}\text { Goodness } \\
\text { of fit }\end{array}$} \\
\hline & & Observed & Expected & & \\
\hline $\mathrm{P}_{1}$ & 40 & 1.28 & 1.29 & 0.25577 & 0.022 \\
\hline $\mathrm{P}_{2}$ & 35 & 3.51 & 3.37 & 0.59009 & 1.275 \\
\hline $\mathrm{F}_{1}$ & 40 & 2.70 & 2.63 & 0.42051 & 0.493 \\
\hline $\mathrm{F}_{2}$ & 198 & 2.09 & 2.48 & 1.73186 & 16.636 \\
\hline $\mathrm{BCP}_{1}$ & 99 & 2.31 & 1.96 & 1.38054 & 9.071 \\
\hline $\mathrm{BCP}_{2}$ & 100 & 3.03 & 3.00 & 0.73646 & 0.144 \\
\hline Midparent & --- & 2.39 & & & $\begin{array}{c}\chi^{2}=27.64 \\
P<0.001\end{array}$ \\
\hline
\end{tabular}

${ }^{\mathrm{z}}$ Rated on the Horsfall-Barratt (1945) scale where higher number indicates more disease.

Table 4. Estimates of additive, dominance, and interaction parameters for the Hawaii 7981 x E228 family.

\begin{tabular}{lcc}
\hline \hline & $\begin{array}{c}\text { Estimate } \\
( \pm \mathrm{SE})\end{array}$ & $t$ test \\
\hline Parameter $^{\mathrm{z}}$ & $0.092 \pm 0.481$ & $0.19^{\mathrm{NS}}$ \\
$\mathrm{m}$ & $-1.119 \pm 0.076$ & $-14.68^{* * * *}$ \\
[ d ] & $5.408 \pm 1.179$ & $4.59^{* * *}$ \\
[ h ] & $2.302 \pm 0.475$ & $4.85^{* * *}$ \\
[i ] & $0.805 \pm 0.329$ & $2.44^{*}$ \\
[j ] & $-2.800 \pm 0.739$ & $3.79^{* * *}$
\end{tabular}

Z Definitions: $\mathrm{m}=$ midpoint (between AA and aa), [d] = difference of AA and aa from midparent, [h] = difference of Aa from midparent value, [i] $=$ homozygote $\times$ homozygote interaction, $[\mathrm{j}]=$ homozygote $\times$ heterozygote interaction, and [1] = heterozygote $\times$ heterozygote interaction. Ns, ${ }^{*}, * * *$ Nonsignificant or significant at $P \leq 0.05$ or 0.001 , respectively.

\section{Discussion}

It is generally believed that hypersensitive responses are controlled by single dominant genes. However, this was not the case with bacterial spot race T3 resistance derived from Hawaii 7981. Earlier, Scott et al. (1996) reported that race T3 hypersensitive response was controlled by a single incompletely dominant gene, $X v 3$. However, evidence is presented herein that genes in addition to $X v 3$ control bacterial spot race $\mathrm{T} 3$ resistance in the field. There was a deficiency of resistant segregates over two seasons in the $\mathrm{F}_{2}$ generation that caused rejection of the expected 1:2:1 incompletely dominant inheritance ratio (Table 1). Furthermore, $\mathrm{F}_{3}$ progeny from the most resistant $\mathrm{F}_{2}$ selections were not as resistant as was Hawaii 7981 (Table 2) despite the fact that these selections generally expressed homozygous hypersensitivity. Moreover, one $\mathrm{F}_{3}$ without hypersensitivity (E223), had more resistance than the susceptible control. Generation means analysis from a family derived from E228 crossed with Hawaii 7981 indicated significant additive, dominant, and epistatic effects that would by necessity require two genes. An actual estimate of the effective factor number was precluded by the epistasis. Due to overlap of the parents with the $F_{1}$ generation, it is not possible to provide evidence for a particular epistatic ratio. A more complex model involving three gene interactions or linkage would require generations not available in these studies (Mather and Jinks, 1982).

Control of resistance to race T3 by $X v 3$ plus other genes presents some difficulties for development of resistant cultivars. It would be straightforward to backcross $X v 3$ into recurrent parents by conducting hypersensitivity tests on plants from each backcross generation. However, if this was done the other resistance genes would likely be lost, and the final resistance obtained might resemble resistance of E228 more than resistance of Hawaii 7981. If such a parent were then crossed to a susceptible parent to make a hybrid cultivar, the intermediate resistance of the hybrid would probably have little value. If both parents had resistance equal to E228, the hybrid would be an improvement over susceptible cultivars; and such hybrids would probably have resistance similar to a hybrid between a susceptible parent and a parent with Hawaii 7981 type resistance. To obtain inbreds with the resistance level of Hawaii 7981 will require modified backcrossing and field selection under high disease pressure. Also, to insure that resistance genes are not lost, $\mathrm{F}_{3}$ or possibly $\mathrm{F}_{4}$ generations would have to be screened between backcrosses so considerable time would be involved. Ultimately resistance in both parents would provide the best resistance. Yet, the first commercially acceptable hybrids would likely have one resistant and one susceptible parent. Although the hybrid would be intermediate (Table 1), this is a good level of resistance which by observation is superior to hybrids heterozygous for race T1 resistance (Scott and Jones, 1989; Scott et al., 1989, 1991).

Control of hypersensitivity to race $\mathrm{T} 3$ by a single incompletely dominant gene (Scott et al., 1996) is simpler than has been reported for race $\mathrm{T} 1$, where it appears that three genes are involved (Wang et al., 1994; Yu et al., 1995) although two genes have also been reported (Whalen et al., 1993). Field studies with race $\mathrm{T} 1$ also indicated that genes for resistance components other than hypersensitivity are required for high levels of resistance (Scott and Jones, 1989; Somodi et al., 1996; Wang, 1992). Thus, breeding for race $\mathrm{T} 1$ resistance is also difficult as has been discussed (Scott et al., 1989, 1991). Without horticulturally acceptable race $\mathrm{T} 1$ recurrent parents, combining race $\mathrm{T} 1$ and race T3 resistance into an acceptable cultivar becomes a formidable task unless tightly linked molecular markers could be found for all the resistance genes. It has not even been possible to evaluate breeding lines for race $\mathrm{T} 1$ resistance in Florida because T3 has essentially replaced T1 (Jones et al., 1998; Jones and Scott, personal observations). Perhaps developing cultivars with only T3 resistance would provide acceptable bacterial spot control in production areas such as Florida. The first cultivars would likely have only one resistant parent, thus allowing some T3 to develop that would probably inhibit $\mathrm{T} 1$ proliferation. However, if cultivars with two resistant parents were developed, T3 could be suppressed to the point that $\mathrm{T} 1$ might emerge.

Given the rather complicated inheritance from the Hawaiian 
resistant sources to races $\mathrm{T} 1$ and $\mathrm{T} 3$, it might be easier to utilize the nonrace specific resistance of PI 114490 (Scott et al., 1997). Such resistance may not be overcome by mutation of new races of $X$. campestris pv. vesicatoria as has been the case with single gene resistance in pepper (Capsicum anпиит L. var. annuиm) cultivars (Kousik and Ritchie, 1996). In tomato, emergence of T3 overcame the race specific, yet multigenic $\mathrm{T} 1$ resistance from Hawaii 7998 and became the predominant race in Florida in the absence of a T1 resistant cultivar (Jones et al., 1998). Inheritance of resistance and breeding strategies for using PI 114490 resistances has not been reported as yet. Resistance from PI 114490 is not as effective to race $\mathrm{T} 3$ as races $\mathrm{T} 1$ and $\mathrm{T} 2$, thus combining resistance from various sources may be another approach for developing broad based and stable resistance to this destructive bacterial disease.

\section{Literature Cited}

Hochmuth, G.J., D.N. Maynard, and M. Sherman. 1989. Tomato production guide for Florida. Fla. Coop. Ext. Circ. 98C:4-11.

Horsfall, J.G. and R.W. Barratt. 1945. An improved grading system for measuring plant diseases. Phytopathology 35:655.

Jones, J.B., H. Bouzar, G.C. Somodi, R.E. Stall, K. Pernezny, G. ElMorsy, and J.W. Scott. 1998. Evidence for the preemptive nature of tomato race 3 of Xanthomonas campestris pv. vesicatoria in Florida. Phytopathology 88:33-38.

Jones, J.B., R.E Stall, J.W. Scott, G.C. Somodi, H. Bouzar, and N.C. Hodge. 1995. A third tomato race of Xanthomonas campestris pv. vesicatoria. Plant Dis. 79:395-398.

Klement, Z. 1982. Hypersensitivity, p. 149-177 In: M.S. Mount and G.H. Lacy (eds.). Phytopathogenic prokaryotes. vol. 2. Academic Press, New York.

Kousik, C.S. and D.F. Ritchie. 1996. Disease potential of pepper bacterial spot pathogen races that overcome the $B s 2$ gene for resistance. Phytopathology 86:1336-1343.

Mather, K. and J.L. Jinks. 1982. Biometrical genetics: the study of continuous variation. 3rd ed. Chapman and Hall, London.

Ng, T.J. 1990. Generation means analysis by microcomputer. HortScience 25:363.

SAS Institute Inc. 1997. SAS user's guide. SAS Inst. Inc., Raleigh, N.C.
Scott, J.W. and J.B. Jones. 1986. Sources of resistance to bacterial spot (Xanthomonas campestris pv. vesicatoria (Doidge) Dye) in tomato. HortScience 21:304-306.

Scott, J.W. and J.B. Jones. 1989. Inheritance of resistance to foliar bacterial spot of tomato incited by Xanthomonas campestris pv. vesicatoria. HortScience 114:111-114.

Scott, J.W., J.B. Jones, and G.C. Somodi. 1989. Genetic resistance to bacterial spot in tomato, p. 200-207 In: S.K. Green (ed.). Tomato and pepper production in the tropics. Asian Veg. Res. Dev. Ctr., Shanhua, Tainan, Republic of China.

Scott, J.W., J.B. Jones, and G. Cameron Somodi. 1991. Disease severity of tomato hybrids heterozygous or homozygous for resistance to bacterial spot: Commercial outlook. Proc. Fla. State Hort. Soc. 104:259262.

Scott, J.W., J.B. Jones, G.C. Somodi, and R.E. Stall. 1995. Screening tomato accessions for resistance to Xanthomonas campestris pv. vesicatoria, race T3. HortScience 30:579-581.

Scott, J.W., S.A. Miller, R.E. Stall, J.B. Jones, G.C. Somodi, V. Barbosa, D.L. Francis, and F. Sahin. 1997. Resistance to race T2 of the bacterial spot pathogen in tomato. HortScience 32:724-727.

Scott, J.W., R.E. Stall, J.B. Jones, and G.C. Somodi. 1996. A single gene controls the hypersensitive response of Hawaii 7981 to race 3 (T3) of the bacterial spot pathogen. Rpt. Tomato Genet. Coop. 46:23.

Somodi, G. Cameron, J.B. Jones, J.W. Scott, J.-F. Wang, and R.E. Stall. 1996. Relationship between the hypersensitive reaction and field resistance to tomato race 1 of Xanthomonas campestris pv. vesicatoria. Plant Dis. 80:1151-1154.

Wang, J.-F. 1992. Resistance to Xanthomonas campestris pv. vesicatoria in tomato. PhD diss. Univ. Florida, Gainesville.

Wang, J.-F., J.B. Jones, J.W. Scott, and R.E. Stall. 1994. Several genes in Lycopersicon esculentum control hypersensitivity to Xanthomonas campestris pv. vesicatoria. Phytopathology 84:702-706.

Whalen, M.C., J.-F. Wang, F.M. Carland, M.E. Heiskell, D. Dahlbeck, G.V.Minsavage, J.B. Jones, J.W. Scott, R.E. Stall, and B.J. Staskawicz. 1993. Avirulence gene avrRxv from Xanthomonas campestris pv. vesicatoria specifies resistance on tomato line Hawaii 7998. Mol. Plant-Microbe Interactions 6:616-627.

Yu, Z.H., J.-F. Wang, R.E. Stall, and C.E. Vallejos. 1995. Genomic localization of tomato genes that control a hypersensitive reaction to Xanthomonas campestris pv. vesicatoria (Doidge) Dye. Genetics 141:675-682. 